\title{
Rhetorical Properties of Scientific Uncertainties: \\ Public Engagement in \\ the Carson Scholars \\ Program
}

Kenny C. Walker

University of Arizona

Tucson, $A Z$

Poroi 10,1 (January 2014)

Keywords: rhetoric of science, uncertainties, transdisciplinary, collaboration, outreach, Carson Scholars Program

\section{Rhetorical Engagement in the Carson Scholars Program}

At last year's ARST preconference, Leah Ceccarelli noted the irony of scholarly communities who spend much of their time making visible obscure points about communication, but who have yet to offer "explicit insight into how a reader can walk the path from understanding to active disruption of norms, restraint of excessive power, or therapeutic intervention in public discussion" (Ceccarelli, $2013,3)$. Developing these insights, she claims, would allow rhetorical scholars "to think about how our basic research supports our outreach in the classroom and in the public and technical spheres, so that we can articulate the means and effects of that transformation of knowledge to ourselves and to others" (4). Embedded in these claims are, I believe warranted, assumptions about rhetorical scholarship. First, rhetorical scholarship has explicit insight into critical social action. Second, rhetorical scholars are the ones who should be enacting these critical messages with their appropriate audiences. Transforming rhetorical scholarship into critical praxis, and therefore the rhetorical scholar into a critical practitioner, is a leap Herndl and Cutlip identify as "applied rhetoric of science" (Herndl \& Cutlip, 2013).

In this brief paper, I reflect on my own leap through a focus on the rhetorical properties of uncertainties in a public science communication program at the University of Arizona. Given the 
focus of this panel on models for outreach, in this report I am mainly concerned to provide an account of the program, its local conditions for rhetorical engagements, and the benefits and drawbacks for scholars of rhetoric of science, technology, and medicine (RSTM). I therefore only describe actual rhetorical engagements in general terms while pointing to related insights in RSTM scholarship. First, I detail the institutional background and the program before I discuss rhetorical properties of uncertainties, and the program's insights for rhetorical praxis in science, technology, and medicine.

The University of Arizona (UA) in Tucson is the state's landgrant institution. It has a student population around 40,000.

Located in the most biologically diverse desert in the world, Tucson is a mixed college, retirement, and tourist community of approximately 1 million people. The city brands itself as "environmentally friendly" and as "a science-city." UA is consistently rated one of the best universities for environmental research in the world (Stolte, 2013). UA's Institute of the Environment is the articulation point for all the environmental work on campus, specializing in climate, geosciences, hydrology, ecology, renewable energy, and more. The scientists at the Institute are directly concerned, and yes, anxious, about the public communication of science. So in 2011 they launched the Carson Scholars Program, named after Rachel Carson. Conceived as a twist on the American Academy for the Advancement of Science's Science Communication Program, and the Ecological Society of America's Aldo Leopold program, both of which work with senior scientists, the Carson Scholars program is built around the idea of funding and mentoring the best environmental graduate students from all disciplines in the public communication of science, and then marketing these graduate students to individual donors in the Tucson community in order to fund their research and its translation into public forums. So the program works like "adopt a pet," except that donors are invited to adopt a graduate student together with a pet research/outreach project.

\section{Pragmatics of the Carson Scholars Program}

The Carson Scholars program accepts 6-10 graduate students per year. Each of us receives $\$ 5,000$ a year to participate in internal program activities, to gain experience in translating our technical research in a variety of public forums, and to publish some portion of our research in a popular genre. Internally, those of us who are 
scholars engage in formal communications training sessions, as well as informal meetings (retreats, lunches, seminars, small lectures, etc.). These activities are meant to build programmatic cohesion and creativity around science and environmental communication. Then the program organizers network us locallythey get us on local PBS stations, into science cafes, on discussion panels after, have us facilitate webinars, etc.-and require the scholars to attempt to publish a popular version of their research. In short, the program pays the best environmental graduate students to become trained and engaged in public science communication.

IPCC contributor, Dr. Julia Cole, and best-selling science writer Chris Cokinos jointly ran the inaugural year of the program. They brought national science communication leaders like Susan Joy Hassol, Jon Krosnic, and Andy Revkin to the university to meet with the Carson Scholars in intimate and informal settings. These settings are where I was able to interest Andy Revkin in the work Dr. Lynda Walsh and I were doing together. That paid off when our research went viral after Revkin profiled one of our articles on his Dot Earth Blog (Revkin, 2012).

The second year, largely run by Dr. Rafe Sagarin, emphasized local networks, and this has lead to us interacting with local non-profit organizers, resource managers, academic scientists, and science writers. For our annual publication project, I was approached by a fellow Carson Scholar and wildlife ecologist, Ashwin Naidu, to help popularize some of his international conservation work. To facilitate this I contacted Ashley Rose Kelly from North Carolina State University, since I had learned she was working with the Public Library of Science (PLOS) citizen science blog. We collaborated on a popular article on international citizen science, remote camera monitoring, and wild tiger conservation in India (Walker, Naidu \& Kelly 2013).

Supporting this work is a mixed public-private funding model for the Carson Scholars program that is perhaps one of its most inventive aspects. The money for the Institute, for its scientists and staff, and particularly for the development director of the program, is public money. But the funding for the graduate students is all privately raised. The development director, Stephanie Sklar, is the one driving private investment in the Carson Scholars program. She is a politically active long-time local with national connections to the Nature Conservancy. She drives private investment primarily by organizing donor events, bringing interested Tucsonans together with the Carson Scholars. One evening every semester we gather at a donor's house in Tucson, and 
eat, drink, and mingle, and then the current scholars give quick five-minute presentations about their work. At the end, the directors sum it up; that brings in the tax-deductible donations. We do other fund-raising too, mostly through local grants from various community organizations. The program is attempting to receive enough in private donations to start an endowment, and last year received its first large donation from a single contributor. The program estimates that once it has a million dollars, an endowment will fund 10-12 scholars per year in perpetuity, not accounting for any other private monies that may come in.

Tucson and the University of Arizona are the right places to make this happen: the combination of world-class faculty and students with a retirement community in a science-city means that this model works well in the location.

\section{The Rhetorical Properties of Uncertainties}

I was fortunate enough to be one of these Carson Scholars during the first two years of the program. My engagements can be characterized by three themes: mixed methods, examples of success, and a research program that focuses on the rhetorical properties of uncertainties. The former two can be described simply; the latter part about uncertainties will need more explanation.

First, in my experience rhetoric draws strength from a pluralistic approach to methods. It behooves rhetoricians to foreground the rhetorical approaches when utilizing multiple methodologies because its methods travel well across disciplinary boundaries. Second, rhetorical engagements in public science communication can benefit from providing examples of success. Often rhetorical engagements reveal how communications fail, or might be done better. Providing specific examples of rhetorical achievements in the past especially inspires scientific audiences to consider that these achievements can be happen again, and this can have great impact on rhetoricians efforts at contemporary engagement.

My own engagements with public science communication start from the premise that rhetoricians offer expertise in deliberation and decision-making under conditions of uncertainty. Uncertainty is an inextricable part of the scientific process. Scientists are highly skilled at managing technical uncertainties to 
solve technical problems, create more certain knowledge, and invent future research questions. But they are not trained in the theory and practice of civic discourse, and therefore lack an explicit understanding of public and political uncertainties, their relationship to technical uncertainties, and how both critically shape civic epistemologies. Without an understanding of different types of uncertainties, they are unable to analyze how technical uncertainties are used by a variety of actors to scaffold public science communication in ways both productive and disruptive to the particular values and goals of a scientific community.

In other words, scientists often do not have a sense of the rhetorical properties of uncertainties-how public/political uncertainties emerge from technical uncertainties in ways that are often provisional, yet greater than the sum of their parts, and potent for the mobilization of political will. By contrast, rhetoricians can reveal the translations of uncertainties in particular cases, helping scientists and science communicators read and respond to kairos as "indeterminate risk management" (Scott, 2006). In using uncertainties to read kairos, rhetoricians have a rich armamentarium of analytic conventions that make critical observations around levels of argument, standards of evidence, warrants, topoi, ethical stances, and so on. But we also have a consistent emphasis on deliberation as an act of prudential judgment in the face of complex situational variables that, while they defy categorization, still critically shape decision-making. So one way to enact a rhetorical expertise is to trace the translations of uncertainties and mark how they condition communicative frameworks and situated choice making within a particular kairos. As others have shown, these rhetorical processes are less about scientific certainty and more about political convictions arrived at through engaging in deliberations that ask public audiences to recall their core values and choose which values to apply to specific cases (Walsh, 2013). In a short time then, a rhetorical emphasis on uncertainties makes explicit a shift in the deliberative framework from scientific knowledge to applied civic epistemologies. Examples of this shift can be found in the RSTM scholarship and its popularization (See for example, Ceccarelli 2011; Walker \& Walsh 2012; Walsh \& Walker 2014; Revkin 2012).

\section{Tensions, Competitions, and Expanding Rhetoric's Kinship}


But not everything is rosy in cactus country. Graduate students already face tremendous pressure to develop a dynamic and publishable research agenda, and the program's emphasis on translating this research into public forums at an early career stage can lead to a few problems. First, students are pressured to translate research when their research agenda hasn't been set, or when the research may be inappropriate for translation. Further, good research simply takes time, and in programs like these there is a genuine tension between the timing for good scholarship and the timing for moments of public intervention. Sometimes you have something, sometimes you don't. Sometimes what you have sticks, sometimes it doesn't. For a number of the graduate student scientists, there is also a real worry that they may be risking their budding reputations by going public too soon-although it is also true that the risks and rewards of public science communication are rapidly changing. For the rhetorician, there is also the problem of lack of support. My life would be easier if I had a fellow ARST member in my English department, or at the medical campus, or in the Communications Department. While I'm fortunate to have long-distance mentoring by RSTM scholars like Lynda Walsh, going it alone means I've had to muddle through some of these engagements and learn on the fly.

This tension is compounded by the level of competition rhetoricians of science, technology \& medicine face across campus in pursuing these outreach efforts. In my experience, scientists value the creative arts, they value the highly empirical social science side of communication studies, and they value the business and corporate communications models. The Carson Scholars program's own communications training, for example, is led by experts in corporate communications, creative writing, empirical communication research, and scientists who have a vast amount of experience in the public communication of science. In this environment, rhetoricians risk being outcompeted. On the other hand, these kinds of opportunities present a genuine opportunity to enhance scientists' understanding of rhetoric, and increase appreciation for its approaches. As Lisa Keränen (2013) noted at last year's preconference, it is incumbent on organizations like ARST to articulate how rhetoric can contribute to public science communication projects in practically useful ways that are not contributed by other disciplines (Keränen, 2013, 5). As witnessed by panels like these, and the many other examples ARST could point to, RSTM scholars have much to offer.

For me personally, the payoff from the Carson Scholars model has been in making visible the theoretical and practical value of 
rhetorical scholarship. Furthermore, the program connected me to environmental scholars on campus whom I have tapped when I had particular questions, or needed external readers on my dissertation. In short, I've been networked into a community that will continue to serve me well in my academic career. If there is a lesson here, it is about the value of translating the findings of our rhetorical scholarship to popular forums. We can do this individually, but it will help to build our own internal networks-establishing something like a public works project team that is primed to seize the growing number of kairotic moments. In the meantime, environmental scientists across my campus continue to acknowledge the fresh perspectives and innovative ideas rhetoricians are bringing to the table. So the take-home for me is to publish the best rhetorical research I am capable of doing, to popularize that published research in high-traffic forums, and to use this approach to expand rhetoric's kinship.

\section{Acknowledgements}

I want to thank the panel chair Jean Goodwin for her efforts in organizing the session, and for her extraordinary editorial guidance. I thank Leah Ceccarelli and Jamie Vernon for their insightful and generous responses. Thanks to my fellow panel members for a memorable experience, to James Wynn for organizing the ARST Preconference, and to David Depew for continuing the relationship between the preconference and Poroi. Finally, I would like to thank the entire Carson Scholars Program, especially Stephanie Sklar, Julie Cole, Chris Cokinos, and Rafe Sagarin.

Copyright (C) 2014 Kenny C. Walker

\section{References}

Ceccarelli, L. (2011). Manufactured scientific controversy: Science, rhetoric, and public debate. Rhetoric and Public Affairs, 14(2), $195-228$.

Ceccarelli, L. (2013). To whom do we speak? The audiences for scholarship on the rhetoric of science and technology. Poroi, 9(1). 
Retrieved from http://ir.uiowa.edu/poroi/vol9/iss1/7/

Herndl, C. \& Cutlip, L. How can we act?: A praxiographical program for the rhetoric of technology, science, and medicine. Poroi, 9(1). Retrieved from http://ir.uiowa.edu/cgi/viewcontent.cgi?article=1163\&context=por oi

Keränen, L. (2013). Conspectus: Inventing futures for the rhetoric of science, technology, and medicine. Poroi, 9(1). Retrieved from oi http://ir.uiowa.edu/cgi/viewcontent.cgi?article $=1167 \&$ context=por

Revkin, A. (2012). How Rachel Carson spurred chemical concerns by highlighting uncertainty. The New York Times: Dot Earth Blog. Retrieved from http://dotearth.blogs.nytimes.com/2012/09/27/how-rachel-carsonspurred-chemical-controls-by-highlighting-uncertainty/?_r=0more-46242

Scott, J.B. (2006). Kairos as indeterminate risk management: The pharmaceutical industry's response to bioterrorism. Quarterly Journal of Speech, 92(2), 115-143.

Stolte, D. (2013). UA ranked top in nation for environmental research. Retrieved from http://uanews.org/story/ua-ranked-top-in-nationfor-environmental-research

Walker, K., Naidu, A., \& Kelly, A.R. (2013). International citizen science for Indian tiger conservation. PLOS Citizen Science Blog. Retrieved from

http://blogs.plos.org/citizensci/2013/04/01/international-citizen-sciencefor-indian-tiger-conservation/

Walker, K., \& Walsh, L. (2012). "No one yet knows what the ultimate consequences may be": How Rachel Carson transformed scientific uncertainty into a site for public participation in Silent Spring. Journal of Business and Technical Communication, 26(1), 3-34.

Walsh, L. \& Walker, K. (2013). Uncertainty, Spheres of Argument, and the Transgressive Ethos of the Science Advisor. In Jean Goodwin, Michael F. Dahlstrom \& Susanna Priest (Eds.), Ethical issues in science communication: A theory-based approach (325-335). Charleston, SC: CreateSpace. 
Walsh, L. (2013). Scientists as prophets: A rhetorical genealogy. New York: Oxford University Press. 